\title{
Improving English Oral Skills through Pair Work and Peer-Peer Dialogue
}

\author{
Raquel Sánchez Ruiz ${ }^{1}$ \\ Universidad de Castilla-La Mancha (Spain) \\ Sonia Lucas Pardo \\ CEIP San Jaime, Onil, Alicante (Spain)
}

\begin{abstract}
The importance of the English language in today's Education system is beyond doubt. Bearing in mind that the Spanish Educational Authorities and regulations advocate the Communicative Approach, this study shows the origin, evolution and results of an innovation project carried out in the English classes at the $4^{\text {th }}, 5^{\text {th }}$ and $6^{\text {th }}$ grades of Primary in a state school in the autonomous community of Valencia (Spain). For that, the authors-teachers employed the methods of action research approach, pair work and peer-peer dialogue supported by the Communicative Approach and collaborative work.

The results will demonstrate the different advantages of employing pair work and peer-peer activities within the classroom not only to improve children's English oral skills but also to contribute to their own personal growth and their development as social citizens.
\end{abstract}

Keywords: classroom research, action research approach, foreign language teaching-learning, pair work, peer-peer dialogue, Primary

\section{RESUMEN}

La importancia de la lengua inglesa en el sistema educativo actual es innegable. Considerando que las Autoridades Educativas españolas y las disposiciones legales vigentes propugnan el Enfoque Comunicativo, el presente estudio muestra el origen, evolución y resultados de un proyecto de innovación llevado a cabo en las aulas de inglés de los cursos,

Corresponding author - Universidad de Castilla-La Mancha (Spain); http://orcid.org/0000-00030022-7734. Email: Raquel.SanchezRuiz@uclm.es 
$4^{\circ}, 5^{\circ}$ y $6^{\circ}$ de Primaria en un colegio público de la Comunidad Valenciana (España). Para ello, los autores-profesores emplearon los métodos de investigación-acción, trabajo en parejas e interacción entre pares, apoyándose a su vez en el Enfoque Comunicativo y el trabajo colaborativo.

Los resultados reflejarán las distintas ventajas de utilizar el trabajo en parejas y actividades realizadas por pares en el aula no solo para mejorar la destreza oral de los alumnos en inglés, sino también para contribuir a su desarrollo personal y como ciudadanos sociales.

Palabras clave: investigación en el aula, investigación-acción, enseñanza-aprendizaje de la lengua extranjera, trabajo en parejas, interacción entre pares, Primaria

\section{Introduction}

The Common European Framework of Reference for Languages (Council of Europe, 2001), as well as the Organic Law of Education (2006) and the Royal Decrees 111/2007 and 108/2014, which regulate the curriculum of Primary Education in the Autonomous Community of Valencia, advocate the Communicative Approach. Therefore, the main focus of attention in the English class is using the foreign language so as to communicate regardless of accuracy; as a consequence, oral communication becomes the cornerstone in the classroom (Gordillo Santofimia, 2011, p. 1). Moreover, English is the most spoken language across the European Union and even the world as it is the lingua franca of today's society (Crystal, 2003). The Spanish Educational Authorities are aware of this relevance; thus, they are both promoting innovation projects whose main line of research is foreign languages and creating European or Bilingual Sections at schools where English predominates.

Bearing that in mind and considering that Spanish pupils, despite having improved in the last few years, still lack skills and rudiments to orally communicate effectively, as Rubio Alcalá and Martínez Lirola $(2008$, p. 51) and the European Commission $(2005,2006)$ demonstrate, we carried out an innovation project to work the oral communicative competence through the Communicative approach, pair work and peer-peer dialogue. The objectives of the mentioned project were: a) to effectually develop the communicative competence in English as well as to gradually improve the acquisition and learning of this language; b) to prioritise the oral skills (listening, speaking and oral interaction) to help children integrate into the information and knowledge society; c) to develop the social and civic competences through team work; d) to develop the learning to learn competence by improving children's academic performance and study skills, especially concerning oral skills, as well as to discover their real educational needs in relation to oral communication and to 
bridge their gaps in an individualised way; e) to complement the didactic material usually utilised in class so as to motivate children with innovating and playful activities which build their interest in learning a foreign language as well as in the different cultures of English-speaking countries; and finally, $f$ ) to involve children in their own learning process through action, reflection, evaluation and self-evaluation.

This study relies on the frames of the Communicative Approach, action research approach, pair work and peer-peer dialogue. First, the Communicative Approach focuses on students' ability to use the language, rather than how much of the grammatical, lexical or phonological resources of the language they know (Morrow, 2012, p. 140). That is, the emphasis is placed on meaning instead of form. Moreover, communicative teaching is aimed at using language in authentic social contexts (Schmid, 2010, p. 159). The use of this approach in the classroom, as Taylor and Wigglesworth remarked (2009, p. 325), resulted in the increasing use of pair work in second language learning contexts. "Pair work is advocated by major theories of second language [L2] learning and research findings suggest that pair work facilitates L2 learning" (Storch \& Aldosari, 2013, p. 31). Some benefits of using pair work in the learning contexts are that learners are given more opportunities to actively use both their receptive and productive language skills and to provide and obtain feedback from other students (Taylor \& Wigglesworth, 2009, p. 326). From a pedagogical perspective, pair work promotes a positive affective climate where students feel less anxious and more confident, improves the quantity and quality of learner talk, promotes learner autonomy and self-directed learning and allows the teacher to assign different tasks to different groups so as to manage a mixed proficiency class (Baleghizadeh, 2009, p. 1). Furthermore, pair work supports interaction, which can facilitate the L2 development by providing learners with comprehensible input, negative feedback and opportunities to modify their output (Gass \& Mackey, 2006). From a sociocultural perspective, the learner is likely to develop their linguistic and cognitive abilities when a more knowledgeable person supports or "scaffolds" a learner socially, cognitively and affectively during interaction (Lantolf \& Thorne, 2006). In this study, this is linked to peer-peer collaborative dialogue, which engages students in problem solving and knowledge building (Swain, 2000, p. 102). It is used in second language learning as learners encounter linguistic problems and attempt to solve them together in a way that language is used both as a communicative and cognitive tool (Swain, Brooks \& Tocalli-Beller, 2002, p. 171). As Zeng and Takatsuka (2009, p. 434) claim, peer-peer collaborative dialogue is of particular significance in the L2 learning process, since "in collaborative dialogue, learners use language to 
reflect on language use, and in doing so, the divide between language use and language learning is overcome with the two co-occurring in the same activity". Furthermore, "during peer interaction learners could assist each other for language development and, at the same time, they may develop a more comprehensive idea of their own L2 knowledge" (Sato \& Ballinger, 2010, p. 158). Finally, this study is embedded in action research, whose purpose is to solve a particular problem and to produce guidelines for best practice (Denscombe, 2010, p. 6). This study has followed Susman's action research model and phases (1983): first, the problem was identified and the data were collected for a more detailed diagnosis (planning). Then, possible solutions were proposed so as to elaborate a plan of action (acting). Data on the results were collected and analysed (observing). And finally the findings were interpreted in relation to the success of the action (reflecting).

Under these premises, the main aim of this paper is to show the origin, evolution and results of a project carried out in the English classes at the $4^{\text {th }}$, $5^{\text {th }}$ and $6^{\text {th }}$ grades of Primary in a state school in the autonomous community of Valencia (Spain) and to demonstrate the different advantages of pair work and peer-peer activities to improve children's English oral skills. In the project, learners had to work in pairs and/or groups to practise the oral skill pronunciation, sentence structure, vocabulary, fluency, etc.- by taking advantage of peer-peer dialogue and collaborative work. Collaboration implies creating "an environment where participants are able to understand the holistic mode of reality where the hole means more than the addition of parts" (Equihua, Borja, Ramírez \& Treviño, 2011, p. 2504).

\section{Data and methodology}

The authors of the present paper are also the English teachers involved in the project. The English teachers carried out the project at the $4^{\text {th }}, 5^{\text {th }}$ and $6^{\text {th }}$ grades of Primary in a state school of a little village in the province of Alicante. The school was located in a rural village from the region L'Alcoià, where most pupils were Valencian- and Spanish-speaking. The school offered both Early Childhood and Primary (two groups per level) Education. It had got 29 teachers, from whom two were English teachers. The school had four linguistic programmes promoting Spanish, Valencian and English at very young ages.

Before starting the project, the teachers held several meetings, first with the school board, then with the teaching staff and later with the parents (planning phase in the action research model). All of them agreed to proceed with the project. So as to demonstrate the actual benefits of the project, in the first 
term, only groups $4^{\text {th }} \mathrm{A}, 5^{\text {th }} \mathrm{A}$ and $6^{\text {th }} \mathrm{A}$ participated in the activities. This approach permitted to compare the results in the exams and academic performance of these courses to those of groups $B^{2}$, which we will show in the analysis section. Since it would have been unfair to deprive groups B of the beneficial effects of the project, in the second term, only these groups participated in the project in order to catch up with groups A. Finally, in the third term, both groups A and B continued with the project as the teachers realised the great improvement in their children's oral skills, which we will also comment in the analysis section. The project started in October and continued until June. The implementation of the project corresponds to the acting phase in the action research model. The teachers implemented the project one hour per week. Apart from the class, every corner of the learning environment was used, for example the playground or the gym, to make the most of the school facilities. The teachers also utilised other resources, such as puppets, to motivate the pupils during the whole process. Furthermore, the teachers sometimes recorded the performance of their pupils during the classes so that the latter could reflect on and observe their progress and so that the former could propose improvement measures (observing and starting point for reflecting phases in the action research model).

Regarding the characteristics of the pupils who participated in the project: $4^{\text {th }} \mathrm{A}$ was a class of six boys and eight girls, who worked quite well -with the exception of three pupils, who reviewed less at home- and the class atmosphere was excellent and motivating, hence their very good and excellent marks. In this class, girls used to have understanding problems, since they normally thought their friends would disappoint them on purpose or mock and ridicule them. $4^{\text {th }} \mathrm{B}$ was a class of five boys and ten girls, who had a very good pace of work; in fact, just one pupil had more problems, but -as she worked hard-she was very motivated and obtained good results. Despite their excellent and hard-working class atmosphere, the pupils got quite concerned when they were assessed; thus, the teachers used relaxing exercises to keep them calm. Furthermore, there was a boy, considered a leader, who sometimes bothered other children. At $5^{\text {th }}$ grade, group A was composed of five boys and ten girls, who worked well. However, there were three pupils with a lower level and constant chattering. There was a female leader, who sometimes bothered other girls, and a pupil with dyslexia. In group B, there were eleven boys and ten girls, who worked well but sometimes just fairly.

2 So as to obtain reliable data and compare the results of each group, the teachers prepared initial, formative and final tests to check pupil's oral skills along the process. We will show the results in the analysis section. 
They were intelligent but it was difficult to motivate them, probably, since there was a pupil diagnosed with Asperger Syndrome who disturbed and disrupted every class. Therefore, the class atmosphere was complicated due to tensions, as this child usually challenged his classmates. Finally, at $6^{\text {th }}$ grade, in group $A$, there were thirteen boys and ten girls, who worked very well, with the exception of four pupils who needed extra help. Moreover, there were problems with some girls, since they even bothered another pupil with their mobiles phones. There was one pupil with individual curricular adaptations as well. In group B, there were nine boys and nine girls, who worked well but were chatty and more active than the rest too. They usually felt the necessity to move when learning. On the one hand, they were hard-workers and motivated, but sometimes social problems arose. Nevertheless, they all helped a pupil with individual curricular adaptations a lot. On the other hand, there were problems with boys and girls, since some boys usually insulted and underestimated another boy, which also happened with girls. In relation to families, all of them were concerned about their children's education in all groups.

On the subject of the methodology of the project, the teachers took the following steps. First, the material was prepared, which included: dialogues, worksheets, guessing activities, card games, flashcards, etc. However, some of the pupils, for instance at fourth grade, prepared materials and brought board games for two different activities: The Market and Guess Who. In The Market, the pupils prepared different market stalls; for that, they brought plastic food and prepared signs with the name of each product in English and their price so that they could buy and sell them afterwards. They also brought cash registers and play money; thus, the simulation was even more genuine and motivating. On the other hand, the pupils brought their Guess Who board games so that the whole class could play at the same time. They had to guess the character that their partners had chosen by asking yes/no-questions.

Second, the teachers distributed the class in pairs or groups, although this was flexible so as to make the most of the different seating arrangements (horseshoe, four-, five- or six-people groups and individually). The teachers took the seating arrangement from the previous classes into account so as to optimise class periods.

Third, the teachers explained the new communicative situation to practise in the first session. However, in the second session, the pupils automatically started practising in pairs as they already knew what they had to do. During those explanations, the teachers dealt with phonetic and phonological, meaning and grammatical aspects. The pupils frequently asked what they did 
not understand since they were in a comfortable and relaxing atmosphere. The practice of the communicative situations lasted several days, always depending on the rate of progress and achievement of objectives. There were two stages in the project: first, controlled practice, where the pupils observed each other; then, free practice, where they exchanged their thoughts about the communicative situation in pairs.

Fourth, except in the classes where the teachers could not move freely because of the pupil with Asperger Syndrome, the teachers always checked the correct oral production of the pupils. For those mentioned cases, the stage of the controlled practice was prolonged before free practice. The teachers distributed the pairs so that there was always a person with a better level who could help the other. When the pairs had practised enough, they performed their communicative situation before the rest of the class.

Finally, the evaluation of the project had three phases, at the same time divided into two subphases. First, the pupils' evaluation was divided into the evaluation by the teachers and self-evaluation. In the evaluation by the teachers, on the one hand, we evaluated their progress in oral communication through the activities done in class; and on the other hand, their oral skills in the final exam. For that, the teachers used evaluation rubrics, with five different levels equivalent to the marks assigned in Primary Education: fail, pass, good, merit and distinction. To apply the rubric, each pupil had to ask two questions: if the questions were right, they obtained 0.4 marks; if the answers were right, they obtained 0.4 marks. They added 0.1 marks for fluency and 0.1 more for pronunciation (rhythm, stress and intonation). On the whole, 1 mark divided into the following parts: 0.2 first question +0.2 first answer + 0.2 second question +0.2 second answer +0.1 fluency +0.1 pronunciation. Following the principles of the Communicative Approach, 'communication' and meaning always prevailed over 'accuracy' and form. The teachers always chose two questions randomly, but the first question was always about the unit which was being worked in class at that moment and the second question was about previous units. In the pupils' self-evaluation, the teachers created evaluation sheets according to the recommendations of the Common European Framework of Reference for Languages (2001), particularly the European Language Portfolio. So, the items showed their progress from a positive perspective, that is, they reflected what they had achieved but not what they could not do yet.

The second phase was the evaluation of the teachers, at the same time, divided into the evaluation by the pupils and self-evaluation. The pupils evaluated both the performance and coordination of the teachers by means 
of a survey. The teachers created and filled in some questionnaires to reflect on the implementation and the coordination of the project. From them, improvement measures arose, which will be commented in the analysis section and considered for future projects.

Finally, the third phase was the evaluation of the process and the product. For the evaluation of the process, the teachers used a questionnaire to evaluate whether the deadlines had been met, whether the employed methodology had been appropriate and why or why not, and so on. The teachers also took notes about the difficulties encountered as well as the positive and negative aspects of the implementation of the project in a diary in each term. As far as the product is concerned, the teachers compared the results from the three exams at the end of each term, mentioned in footnote 2 . The first exam was the starting point for the project and permitted to lay the foundations and adjust the best methodology in each class, the second exam let the teachers measure the progress of the pupils in the project and the third exam measured the benefits of the project in the pupils' oral skills.

\section{Results}

As mentioned before, at the beginning of the project, the teachers carried out an initial evaluation in all groups to check their pupils' level and to be able to compare the results at the end of each term and at the end of the year. It must be noted that, in this first term, groups $A$ were the sample or experimental groups, and groups $B$, the control groups. Table 1 shows the results of the initial evaluation:

\begin{tabular}{|l|l|l|l|l|l|l|}
\hline Initial test \\
\hline & Fail & Pass & Good & Merit & Distinction & TOTAL \\
\hline $4^{\text {th }}$ grade \\
\hline Group A & 3 & 8 & 3 & 0 & 0 & 14 \\
\hline Group B & 7 & 3 & 1 & 3 & 1 & 15 \\
\hline TOTAL & 10 & 11 & 4 & 3 & 1 & 29 \\
\hline $5^{\text {th }}$ grade \\
\hline Group A & 7 & 5 & 3 & 0 & 0 & 15 \\
\hline Group B & 6 & 3 & 9 & 2 & 1 & 21 \\
\hline TOTAL & 13 & 8 & 12 & 2 & 1 & 36 \\
\hline $6^{\text {th }}$ grade \\
\hline Group A & 3 & 6 & 5 & 4 & 5 & 23 \\
\hline Group B & 3 & 8 & 2 & 3 & 2 & 18 \\
\hline TOTAL & 6 & 14 & 7 & 7 & 7 & 41 \\
\hline
\end{tabular}

Table 1. Results of the initial evaluation 
Then, at the end of the term, the teachers carried out another evaluation to check the influence of the project as well as the development of the classes. Table 2 shows these results:

\begin{tabular}{|l|l|l|l|l|l|l|}
\hline \multicolumn{7}{|l|}{ First term } \\
\hline \multicolumn{7}{|l|}{} \\
\hline $4^{\text {th }}$ grade & Fail & Pass & Good & Merit & Distinction & TOTAL \\
\hline Group A & 1 & 4 & 1 & 3 & 5 & 14 \\
\hline Group B & 0 & 3 & 2 & 6 & 4 & 15 \\
\hline TOTAL & 1 & 0 & 3 & 9 & 9 & 29 \\
\hline $5^{\text {th }}$ grade \\
\hline Group A & 4 & 3 & 1 & 3 & 4 & 15 \\
\hline Group B & 1 & 4 & 0 & 9 & 7 & 21 \\
\hline TOTAL & 5 & 7 & 1 & 11 & 11 & 36 \\
\hline $6^{\text {th }}$ grade \\
\hline Group A & 1 & 1 & 1 & 4 & 16 & 23 \\
\hline Group B & 1 & 0 & 2 & 4 & 11 & 18 \\
\hline TOTAL & 2 & 1 & 3 & 8 & 27 & 41 \\
\hline
\end{tabular}

Table 2. Results at the end of the first term

In the second term, the groups swapped their roles, that is, groups A became the control groups and groups B, the experimental groups, so that they could catch up with the former and benefit from the project as well. Table 3 shows the results of the second term:

\begin{tabular}{|l|l|l|l|l|l|l|}
\hline \multicolumn{7}{|l|}{ Second term } \\
\begin{tabular}{|l|l|l|l|l|l|l|}
\hline & Fail & Pass & Good & Merit & Distinction & TOTAL \\
\hline $4^{\text {th }}$ grade \\
\hline Group A & 1 & 2 & 1 & 3 & 7 & 14 \\
\hline Group B & 0 & 0 & 0 & 5 & 10 & 15 \\
\hline TOTAL & 1 & 2 & 1 & 8 & 17 & 29 \\
\hline $5^{\text {th }}$ grade \\
\hline Group A & 0 & 2 & 1 & 9 & 3 & 15 \\
\hline Group B & 0 & 3 & 3 & 5 & 10 & 21 \\
\hline TOTAL & 0 & 5 & 4 & 14 & 13 & 36 \\
\hline $6^{\text {th }}$ grade \\
\hline Group A & 1 & 4 & 1 & 10 & 7 & 23 \\
\hline Group B & 1 & 2 & 4 & 7 & 4 & 18 \\
\hline TOTAL & 2 & 6 & 5 & 17 & 11 & 41 \\
\hline
\end{tabular}
\end{tabular}

Table 3. Results at the end of the second term

Finally, in the third term, both groups at all grades participated in the project, with the following results: 


\begin{tabular}{|l|l|l|l|l|l|l|l|}
\hline Third term & Fail & Pass & Good & Merit & Distinction & TOTAL \\
\hline \multicolumn{7}{|l|}{} \\
\hline $4^{\text {th }}$ grade \\
\hline Group A & 0 & 1 & 0 & 5 & 8 & 14 \\
\hline Group B & 0 & 0 & 0 & 7 & 8 & 15 \\
\hline TOTAL & 0 & 1 & 0 & 12 & 16 & 29 \\
\hline $5^{\text {th }}$ grade \\
\hline Group A & 0 & 1 & 1 & 9 & 4 & 15 \\
\hline Group B & 0 & 3 & 2 & 9 & 7 & 21 \\
\hline TOTAL & 0 & 4 & 3 & 18 & 11 & 36 \\
\hline $6^{\text {th }}$ grade \\
\hline Group A & 1 & 0 & 5 & 6 & 11 & 23 \\
\hline Group B & 0 & 2 & 2 & 7 & 7 & 18 \\
\hline TOTAL & 1 & 2 & 7 & 13 & 18 & 41 \\
\hline
\end{tabular}

Table 4. Results at the end of the third term

Now, we proceed to explain the development of the project and its impact on the obtained results. As Table 1 shows, at $4^{\text {th }}$ grade pupils' marks ranged from fail to distinction. After implementing the project, the number of fails in the experimental group was more than halved, and some of the initial passes and goods became merits and distinctions. However, we also observed that the control group also improved their marks with the development of the usual English classes; in fact, no one failed at the end of the first term. In this regard, it must be noted that in the usual classes, the teachers prioritised oral skills at all grades and emphasis was placed more on meaning than on form under the Communicative Approach. In the second term, while the control group -now groups A- managed to keep their marks to acceptable standards, the experimental group improved their marks, especially in the number of distinctions, which consisted of two thirds of the class; moreover, there were no fails, passes or goods; thus, the lower marks were merits. Finally, in the third term, when the teachers implemented the project in both groups, all the marks in both groups and at all grades improved; that is, every child obtained a merit or a distinction with the exception of only one pupil.

At $5^{\text {th }}$ grade, the initial test resulted in a wide range of marks in group $B$. However, in group A, none of the children obtained a merit or a distinction. After the implementation of the project, group-A's marks improved -as even some of them obtained merits and distinctions- although some pupils did not reach the objectives and failed. Again, as at $4^{\text {th }}$ grade, the development of the usual classes made the control group improve their marks as well. In the second term, the now experimental group, who had better marks from the beginning, improved their marks, since there were no fails and almost half of 
the class obtained excellent marks. In the third term, the project proved to be beneficial for both groups as none of the pupils failed and most of them obtained a merit and a distinction.

Finally, $6^{\text {th }}$-grade pupils had the best level, since in the initial test only few failed; however, only few got a distinction as well. After implementing the project, the experimental group managed to improve their marks up to the ranges of merit and distinction. Nevertheless and as at the rest of the grades, the control group also improved their marks with the development of the usual classes. In the second term, on the one hand, the experimental group kept their marks to acceptable standards, with some exceptions though, since the number of distinctions decreased. On the other hand, the control group suffered the lack of the project in this term, since their marks decreased as well; however, in the third term, when the teachers implemented the project again in this group, both groups improved their marks -especially compared to the results in the initial test- and mainly obtained merits and distinctions.

Regarding the results of the evaluation questionnaires, there were three parts the pupils had to fill in. The first part was the children's self-evaluation, which at the same time we divided into two subparts: in the first subpart (questions 1-4), common to all grades, they had to say whether they had improved their fluency, intonation and pronunciation in English as well as learned and acquired new words with the project. The second subpart was specifically addressed to each one of the grades; therefore, at $4^{\text {th }}$ grade (questions 5-12), the pupils had to mark whether they knew how to say when their birthday was, to ask what time it was, to use the verb 'to have', to ask for and give instructions, to ask and answer about the weather, to ask and answer using the Present Continuous, to physically describe a person, to ask for and serve food, to ask and say how much something cost and to say the days of the week, months and seasons. At $5^{\text {th }}$ grade (questions 13-19), they had to mark if they were able to use the verbs 'to have' and 'to like' and the Present Simple as well as the adverbs of frequency, to ask with 'how long', to compare, to use modal verbs such as 'can' and the structures 'there is/are' and the quantifiers 'some/any'. At $6^{\text {th }}$ grade (questions 20-28), the pupils had to confirm if they knew how to use the Present Simple, the Present Continuous and the superlative; to express the time and their likes and dislikes, to speak about what they were wearing, to use the structure 'there is/are' and the Past Simple of the verb 'to be' with places; and finally, to use the Past Simple of common regular verbs.

With the second part of the questionnaire, the pupils had to evaluate the teachers (questions 29-39); thus, children had to answer yes or no to questions 
related to the clarity of the teachers' explanations of tasks and activities, if they understood the teachers, the teachers' attitude towards their pupils' understanding, if the teachers helped them, if the teachers spoke in English, if the teachers motivated them and made them like the subject and the language and also feel comfortable, if the teachers knew what to do at each moment, and if the teachers devoted the same time to all pupils.

Finally, the third part was about the evaluation of the process and the project itself. Again, there were two subparts: the first one (questions 40-44) referred to the impact of the project on the pupils' motivation; it also appealed to their emotions, since the teachers asked their pupils if they liked the project at a personal level; they were also asked if they felt comfortable working with both the activities of the project and the book; and also about the future, that is, if they would like to include ICT in the project and if they would like to continue with the project the following year. The second subpart (questions 45-48) consisted of open questions, which mainly measured the pupils' emotions and feelings towards the project, since the teachers asked them about those aspects that they liked most and least and they found easier and more difficult. Moreover, before filling in this questionnaire, the teachers gave them the following instructions: each pupil will fill in the following questionnaire anonymously. Be honest and polite. This has three parts so that you can evaluate your own participation in the project, the teachers and the process itself. Read all the questions carefully and ask the teachers if necessary.

Now we proceed to show the results of the questionnaires at each grade:

\begin{tabular}{|c|c|c|c|c|c|c|c|c|c|c|c|c|c|c|c|c|c|}
\hline \multicolumn{18}{|c|}{ Groups $4^{\text {th }} A$ and $4^{\text {th }} B$} \\
\hline \multicolumn{18}{|c|}{ Part 1: Pupils'self-evaluation } \\
\hline \multicolumn{2}{|c|}{ Question number: } & 1 & 2 & 3 & 4 & & 5 & trat & 6 & 7 & 8 & 9 & & 10 & 11 & 12 & 13 \\
\hline \multirow[t]{2}{*}{ Yes } & $4^{\text {th }} \mathrm{A}$ & 14 & 14 & 14 & 14 & & 14 & & 14 & 14 & 14 & 11 & & 13 & 13 & 14 & 12 \\
\hline & $4^{\text {th }} B$ & 12 & 15 & 13 & 14 & & 14 & & 15 & 14 & 14 & 14 & & 14 & 14 & 15 & 13 \\
\hline \multirow[t]{2}{*}{ No } & $4^{\text {th }} \mathrm{A}$ & 0 & 0 & 0 & 0 & & 0 & - & 0 & 0 & 0 & 3 & & 1 & 1 & 0 & 2 \\
\hline & $4^{\text {th }} B$ & 3 & 0 & 2 & 1 & & 1 & trat & 0 & 1 & 1 & 1 & & 1 & 1 & 0 & 2 \\
\hline \multicolumn{18}{|c|}{ Part 2: Teachers' evaluation } \\
\hline \multicolumn{2}{|c|}{ Question number: } & 30 & 31 & 32 & & 33 & & 34 & & & 36 & & 37 & & 8 & 39 & 40 \\
\hline \multirow[t]{2}{*}{ Yes } & $4^{\text {th }} \mathrm{A}$ & 13 & 14 & 12 & & 14 & & 14 & 1 & & 12 & & 14 & & 4 & 10 & 10 \\
\hline & $4^{\text {th }} B$ & 14 & 15 & 14 & & 13 & & 14 & 1 & & 12 & & 13 & 1 & 4 & 11 & 14 \\
\hline \multirow[t]{2}{*}{ No } & $4^{\text {th }} \mathrm{A}$ & 1 & 0 & 2 & & 0 & & 0 & 2 & & 2 & & 0 & 0 & & 4 & 4 \\
\hline & $4^{\text {th }} B$ & 1 & 0 & 1 & & 2 & & 1 & 5 & & 3 & & 2 & 1 & & 4 & 1 \\
\hline
\end{tabular}

Table 5. Results of the questionnaire at $4^{\text {th }}$ grade 


\begin{tabular}{|l|l|l|l|l|l|l|}
\hline \multicolumn{2}{|l|}{ Part 3: Evaluation of the process } \\
\hline Question number: & 41 & 42 & 43 & 44 & 45 \\
\hline \multirow{3}{*}{ Yes } & $4^{\text {th }} \mathrm{A}$ & 13 & 13 & 13 & 11 & 13 \\
\cline { 2 - 7 } & $4^{\text {th }} \mathrm{B}$ & 11 & 13 & 10 & 10 & 10 \\
\hline \multirow{2}{*}{ No } & $4^{\text {th }} \mathrm{A}$ & 1 & 1 & 1 & 3 & 1 \\
\cline { 2 - 8 } & $4^{\text {th }} \mathrm{B}$ & 4 & 2 & 5 & 5 & 5 \\
\hline
\end{tabular}

Table 5. Results of the questionnaire at $4^{\text {th }}$ grade (cont.)

Regarding the open questions at $4^{\text {th }}$ grade, both groups liked speaking in public the least; in fact, they considered this as the most difficult part in the project. On the contrary, group A really enjoyed the games and working in pairs. It is interesting that they acknowledged that the project helped them to understand the units seen in the usual classes. And group B stated that they liked games and performances and found it easy to work in pairs. They also mentioned that they liked making new friends when working in pairs due to the project.

At $5^{\text {th }}$ grade, these were the results:

\begin{tabular}{|c|c|c|c|c|c|c|c|c|c|c|c|c|}
\hline \multicolumn{13}{|c|}{ Groups $5^{\text {th }} A$ and $5^{\text {th }} B$} \\
\hline \multicolumn{13}{|c|}{ Part 1: Pupils' self-evaluation } \\
\hline \multicolumn{2}{|c|}{ Question number: } & 1 & 2 & 3 & 4 & 14 & 15 & 16 & 17 & 18 & 19 & 20 \\
\hline \multirow[t]{2}{*}{ Yes } & $5^{\text {th }} \mathrm{A}$ & 14 & 14 & 14 & 14 & 15 & 14 & 11 & 15 & 15 & 14 & 14 \\
\hline & $5^{\text {th }} B$ & 21 & 20 & 18 & 21 & 19 & 20 & 19 & 19 & 20 & 20 & 20 \\
\hline \multirow[t]{2}{*}{ No } & $5^{\text {th }} \mathrm{A}$ & 1 & 1 & 1 & 1 & 0 & 1 & 3 & 0 & 0 & 1 & 1 \\
\hline & $5^{\text {th }} B$ & 0 & 1 & 3 & 0 & 2 & 1 & 2 & 2 & 1 & 1 & 1 \\
\hline \multicolumn{13}{|c|}{ Part 2: Teachers' evaluation } \\
\hline \multicolumn{2}{|c|}{ Question number: } & 30 & 31 & 32 & 33 & 34 & 35 & 36 & 37 & 38 & 39 & 40 \\
\hline \multirow[t]{2}{*}{ Yes } & $5^{\text {th }} \mathrm{A}$ & 14 & 14 & 14 & 14 & 15 & 14 & 11 & 15 & 15 & 14 & 14 \\
\hline & $5^{\text {th }} B$ & 20 & 20 & 19 & 21 & 13 & 8 & 16 & 20 & 20 & 18 & 18 \\
\hline \multirow[t]{2}{*}{ No } & $5^{\text {th }} \mathrm{A}$ & 1 & 1 & 1 & 1 & 0 & 1 & 3 & 0 & 0 & 1 & 1 \\
\hline & $5^{\text {th }} B$ & 1 & 1 & 2 & 0 & 8 & 13 & 5 & 1 & 1 & 3 & 3 \\
\hline \multicolumn{13}{|c|}{ Part 3: Evaluation of the process } \\
\hline \multicolumn{2}{|c|}{ Question number: } & 41 & \multicolumn{3}{|c|}{42} & \multicolumn{3}{|l|}{43} & \multicolumn{2}{|c|}{44} & \multicolumn{2}{|c|}{45} \\
\hline \multirow[t]{2}{*}{ Yes } & $5^{\text {th }} \mathrm{A}$ & 14 & \multicolumn{3}{|c|}{13} & \multicolumn{3}{|l|}{11} & \multicolumn{2}{|c|}{11} & \multicolumn{2}{|c|}{13} \\
\hline & $5^{\text {th }} B$ & 13 & \multicolumn{3}{|c|}{15} & \multicolumn{3}{|l|}{18} & \multicolumn{2}{|c|}{13} & \multicolumn{2}{|c|}{18} \\
\hline \multirow[t]{2}{*}{ No } & $5^{\text {th }} \mathrm{A}$ & 1 & \multicolumn{3}{|c|}{2} & \multicolumn{3}{|l|}{4} & \multicolumn{2}{|c|}{4} & \multicolumn{2}{|c|}{2} \\
\hline & $5^{\text {th }} B$ & 8 & \multicolumn{3}{|l|}{6} & \multicolumn{3}{|l|}{3} & \multicolumn{2}{|l|}{8} & \multicolumn{2}{|c|}{3} \\
\hline
\end{tabular}

Table 6. Results of the questionnaire at $5^{\text {th }}$ grade

In relation to the open questions, again, both groups agreed with the fact that speaking in public was the aspect they liked the least and the most difficult 
one. Likewise, group A liked games and working in pairs the most. The fact that they appreciated and enjoyed whole sessions speaking in English is remarkable. Group B liked games as well as activities in the playground, since they claimed that it was fun to do something new. On the contrary, many pupils thought it was hard to work in pairs or in groups because they were not used to that.

Finally, the results of $6^{\text {th }}$ grade were as follows:

\begin{tabular}{|c|c|c|c|c|c|c|c|c|c|c|c|c|c|c|}
\hline \multicolumn{15}{|c|}{ Groups $6^{\text {th }} A$ and $6^{\text {th }} B$} \\
\hline \multicolumn{15}{|c|}{ Part 1: Pupils' self-evaluation } \\
\hline \multicolumn{2}{|c|}{ Question number: } & 1 & 2 & 3 & 4 & 21 & 22 & $2 \quad 23$ & 24 & 25 & 26 & \begin{tabular}{l|l}
5 & 27 \\
\end{tabular} & 28 & 29 \\
\hline \multirow[t]{2}{*}{ Yes } & $6^{\text {th }} \mathrm{A}$ & 22 & 22 & 19 & 23 & 22 & 21 & 122 & 22 & 22 & 22 & 223 & 23 & 22 \\
\hline & $6^{\text {th }} \mathrm{B}$ & 16 & 17 & 17 & 18 & 17 & 716 & $5 \quad 17$ & 14 & 17 & 15 & $5 \quad 18$ & 15 & 18 \\
\hline \multirow[t]{2}{*}{ No } & $6^{\text {th }} \mathrm{A}$ & 1 & 1 & 4 & 0 & 1 & 2 & 1 & 1 & 1 & 1 & 0 & 0 & 1 \\
\hline & $6^{\text {th }} B$ & 2 & 1 & 1 & 0 & 1 & 2 & 1 & 4 & 1 & 3 & 0 & 3 & 0 \\
\hline \multicolumn{15}{|c|}{ Part 2: Teachers' evaluation } \\
\hline \multicolumn{2}{|c|}{ Question number: } & 30 & 31 & 32 & & 33 & 34 & 35 & 36 & & 37 & 38 & 39 & 40 \\
\hline \multirow[t]{2}{*}{ Yes } & $6^{\text {th }} \mathrm{A}$ & 23 & 22 & 22 & & 23 & 22 & 20 & 19 & & 23 & 18 & 23 & 13 \\
\hline & $6^{\text {th }} B$ & 14 & 18 & 18 & & 18 & 17 & 18 & 16 & & 17 & 17 & 18 & 10 \\
\hline \multirow[t]{2}{*}{ No } & $6^{\text {th }} \mathrm{A}$ & 0 & 1 & 1 & $\mathrm{C}$ & & 1 & 3 & 4 & & 0 & 5 & 0 & 10 \\
\hline & $6^{\text {th }} B$ & 4 & 0 & 0 & $c$ & & 1 & 0 & 2 & & 1 & 1 & 0 & 8 \\
\hline \multicolumn{15}{|c|}{ Part 3: Evaluation of the process } \\
\hline \multicolumn{2}{|c|}{ Question number: } & \multicolumn{2}{|l|}{41} & \multicolumn{3}{|c|}{42} & \multicolumn{2}{|c|}{43} & \multicolumn{3}{|c|}{44} & & \multicolumn{2}{|c|}{45} \\
\hline \multirow[t]{2}{*}{ Yes } & $6^{\text {th }} \mathrm{A}$ & \multicolumn{2}{|l|}{23} & \multicolumn{3}{|c|}{22} & \multicolumn{2}{|c|}{22} & \multicolumn{3}{|c|}{23} & \multicolumn{3}{|c|}{22} \\
\hline & $6^{\text {th }} B$ & \multicolumn{2}{|l|}{15} & \multicolumn{3}{|c|}{15} & \multicolumn{2}{|c|}{15} & \multicolumn{3}{|c|}{17} & \multicolumn{3}{|c|}{18} \\
\hline \multirow[t]{2}{*}{ No } & $6^{\text {th }} \mathrm{A}$ & \multicolumn{2}{|l|}{0} & \multicolumn{3}{|c|}{1} & \multicolumn{2}{|l|}{1} & \multicolumn{3}{|c|}{0} & 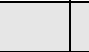 & 1 & \\
\hline & $6^{\text {th }} B$ & 3 & & 3 & & & 3 & & 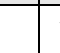 & & & & 1 & \\
\hline
\end{tabular}

Table 7. Results of the questionnaire at $6^{\text {th }}$ grade

Concerning the open questions, once again, both groups expressed that speaking in front of their classmates was the most difficult part of the project and what they liked the least. On the one hand, group A not only liked working in pairs but also helping others. Moreover, they found it easy to learn the grammar and vocabulary of each unit with the methodology employed in the project. On the other hand, group $B$ also liked working in pairs although they recognised that, at times, it was complicated to explain some things to their peers. They also liked working with people with different levels of English and games.

Under these premises, the teachers can claim that, on the whole, selfevaluations were very positive, since no more than five children ever assigned negative responses. However, there is an exception, group $5^{\text {th }} \mathrm{B}$, where half of 
the class considered that the teachers neither spoke slowly nor adjusted to their learning pace. What is more, this same group did not appraised the project positively regarding motivation and they also said that they wanted neither to implement the project by using ICT nor to repeat this experience in the future. Having this in mind, it is inspiring that most of the children reflected on their own learning and work and enjoyed the project; therefore, they have learned while having fun. Furthermore, some acknowledged not only having learned academic issues but strategies for their own personal development; for example, building friendships in the activities of the project. Moreover, the project also worked competences, such as the social and civic competences as well as social skills, in essence, transversal competences. Despite the mentioned group, the rest confirmed that they were motivated by the project and even explicitly appreciated that the whole sessions were in English.

The teachers' evaluation was also completely positive. Nevertheless, some aspects need improvement in future implementations of the project. For example, a better adjustment of the tasks, since sometimes, the pupils needed more time to practise in front of the class. Moreover, even if the methodology was varied and the teachers employed multiple materials, introducing ICT would be an aspect to consider. The teachers must also bear in mind that, as in this year, the planning must be flexible, as it has to be adapted to the reality of the classroom and the teachers have to choose and modify activities and tasks so that the pupils consolidate learning and the process is meaningful, especially at the beginning when the teachers have to adjust the pace of the class to the pupils. Regarding the combination of the usual planning with the project not only was it compatible but also advisable since the teachers used many of the activities to reinforce content or introduce topics. Motivation was generally high except for the critical group mentioned before. Maybe the pupil with Asperger Syndrome as well as other several problems were a source of lack of motivation. However, the project also helped children to speak in public, since at the beginning some of them had stage panic, which progressively disappeared. On the whole, the teachers can affirm that the project had a qualitative impact both on the children's academic performance and on their personal development and other transversal competences.

\section{Claims and conclusions}

Even if some difficulties and problems arose at the beginning, especially due to the low English level of the pupils or because they were not used to the methodology employed, the authors-teachers can claim that the project was a great success. It was so not only due to their academic results, but also for 
their achievements, like more motivation, more fluency, more reflection on their own work and self-evaluation, the acquisition of a taste for the English language and social skills, among others.

Moreover, the project served to equate and raise the level of the classes, that is, it helped the children with worse marks and less disposition or ability for languages and to reinforce what they had learned in the usual classes and even to introduce topics and acquire language in a playful way. Therefore, it constituted a tool to attend to diversity and get a more homogenous level. Likewise, the project made use of a more active methodology, where the teachers prioritised oral skills and everyone spoke only English during the whole sessions; thus, children had to actively listen to the teachers and their peers and they reflected more on their own learning as they had to check and use peer correction and accept their own mistakes as part of the learning process, as Gass and Mackey (2006) and Sato and Ballinger (2010) demonstrated. Then, self-criticism, critical thinking, self-confidence and autonomy were also worked; in essence, sense of initiative and entrepreneurship and learning to learn competences.

Even though, at the beginning, some pupils felt uncomfortable and did not want to work if the teachers had already listened to them or checked their work, they had to be scolded for that and the teachers had to check they had done their tasks. In this sense, the project helped them to organise their work better, since they had to learn useful expressions to improve their vocabulary and use them in similar situations in the future, which also allowed children to be more and more spontaneous in their interactions. Some children even asked the teachers if they could practise their conversations before so that their performance in the class was better. The project, then, encouraged the children to study (not only the language itself but also aspects like intonation, gestures and strategies for oral presentations), overcome their own fears, and challenge and surpass themselves.

Furthermore, the activities and tasks in the project trained them for the exam. What is more, once they were used to the methodology, improvisation activities were carried out with excellent results. These good results motivated the pupils not only to learn but also to volunteer in tasks, especially in those were they had to speak before their classmates. As the project advanced, even the sceptics accepted that the textbook is not the only source of knowledge, but guided practical and didactic tasks teach knowledge, especially if the pupils did them in a fun way, and reinforce and consolidate contents as well. Obtaining a reward sticker for doing their activities and performing their 
dialogues motivated them and encouraged them to actively participate in the classes.

Likewise, these results encourage the teachers to implement the project in future academic years; especially repeating those activities which turned out to be more dynamic and motivating, like buying and selling products in a market created ad hoc with different materials (plastic food, empty containers, cash registers, play money, etc.), card battles and Guess who. What is more, the teachers could implement the project with due modifications to work or go into detail about other competences, like the digital competence, by working and evaluating ICT; cultural awareness and expression, by making pupils create their own materials; the social and civic competences, by planning more team and cooperative work; and sense of initiative and entrepreneurship, by applying the task-based approach, among others. Or by employing other methodologies, such as storytelling or TPR, that would allow children to improve their academic results in the different English skills or by using other more motivating materials that would contribute to the acquisition of a taste for reading or that would appeal more to their interests or to promote or improve other issues.

However, for future editions, the authors would like to involve as many members of the teaching staff of the centre as possible and to achieve greater participation and further dissemination of the benefits and results. And, in the particular case of English, more support -be that logistic support or the creation of working groups- in order to distribute the work, since sometimes, such as in the evaluation of oral exams or the creation of materials, it was difficult to carry out some activities due to a lack of time. On the other hand, the teachers would like to extend the project to other centres -as another school visited our centre and the teachers found the idea interesting and were amazed by the results- and, so, create a working network so as to obtain more support and disseminate the results.

Likewise, the teachers could take the orientation staff into consideration, especially in relation to some children's behaviour issues, like the case of Asperger Syndrome. Maybe some relaxation techniques and behavioural rules would make integration easier and those types of pupils would not disrupt the classes, so the atmosphere would be more suitable. This would make a difference since the teachers had confirmed that relaxation techniques helped those children who were more demanding of themselves to effectively improve their academic performance and, of course, their emotional state. 
Finally, the theoretical assumptions on which this study is based can prove to be useful in the dissemination of results and creation of guidelines for better teaching practice. Moreover, this paper contributes to a better understanding of the collaborative learning process in the line of other works like Zeng and Takatsuka (2009) or Watanabe and Swain (2007), and to reflecting on the target language so as to raise a meta-linguistic awareness as in Swain (2000). And, as Sato and Ballinger (2010) demonstrated, projects like this help learners develop a more comprehensive and real idea of their own L2 knowledge. Besides, collaborative work and peer-peer dialogue are confirmed to be essential in communicative language teaching as it allows learners to express meaning in authentic contexts.

\section{About the author}

Raquel Sánchez Ruiz, PhD, is an Assistant Professor (Tenure Track) at the Faculty of Education in Albacete (Universidad de Castilla-La Mancha). Her research interests include EFL acquisition/learning, CLIL, English Didactics and Methodology and Education Innovation. Address for correspondence: Facultad de Educación (Edificio Simón Abril), Plaza de la Universidad, $n^{\circ} 3$, CP 02071, Albacete, Spain (Raquel.SanchezRuiz@uclm.es)

Sonia Lucas Pardo is a Primary and English teacher in CEIP San Jaime, Onil, Alicante (Spain). She was a former English Primary teacher in Colegio Mare de Dèu de Gràcia, Biar, Alicante. Her research interests include EFL acquisition/learning, English Didactics and Methodology and Education Innovation. Email: soniacloe8@hotmail.com.

\section{Acknowledgements}

We would like to thank the two anonymous reviewers, especially reviewer 1 , of this paper for their insightful comments and suggestions on an earlier version. 


\section{Article history}

Paper received: $22^{\text {nd }}$ September 2015

Paper received in revised form and accepted for publication: $22^{\text {nd }}$ December 2015

\section{References}

Baleghizadeh, S. (2009). Investigating the Effectiveness of Pair Work on a Conversational Cloze Task in EFL Classes. TESL Reporter, 42(2), 1-12.

Council of Europe (2001). Common European Framework of Reference for Languages. Cambridge: Cambridge University Press.

Crystal, D. (2003). English as a Global Language. Cambridge: Cambridge University Press.

Decreto 111/2007, de 20 de julio, del Consell, por el que se establece el currículo de la Educación Primaria en la Comunitat Valenciana [2007/9730]. July, $20^{\text {th }} 2007$. Diari Oficial de la Comunitat Valenciana, 5562.

Decreto 108/2014, de 4 de julio, del Consell, por el que se establece el currículo y desarrolla la ordenación general de la educación primaria en la Comunitat Valenciana [2014/6347]. July, $4^{\text {th }}$ 2014. Diari Oficial de la Comunitat Valenciana, 7311.

Denscombe, M. (2010). The Good Research Guide: For Small-Scale Social Research Projects. Berkshire: Open University Press.

Equihua, L., Borja, V., Ramírez, A., \& Treviño, A. (2011). Education under Product/Project Oriented Learning Technic, an Academic Experience Under Multidisciplinary and Collaborative Work Environment. INTED2011 Proceedings, 2504-2510.

European Commission (2005). Eurobarometer 231 - Wave 63.4. Retrieved from http://ec.europa.eu/public_opinion/archives/ebs/ebs_237.en.pdf

European Commission (2006): Special Eurobarometer 243 - 64.3. Retrieved from http://ec.europa.eu/public_opinion/archives/ebs/ebs_243_en.pdf

Gass, S., \& Mackey, A. (2006). Input, Interaction and Output. AlLA Review, 19, 3-17.

Gordillo Santofimia, L. M. (2011). Desarrollo de la comunicación oral en la clase de inglés. Revista digital: Innovación y experiencias educativas, 38, 1-9.

Lantolf, J. P., \& Thorne, S. L. (2006). Sociocultural Theory and the Genesis of Second Language Development. Oxford: Oxford University Press.

Ley Orgánica 2/2006, de 3 de mayo, de Educación. May, $3^{\text {rd }}$ 2006. Boletín Oficial del Estado, 106. 
Morrow, K. (2012). Communicative Language Testing. In C. Coombe, P. Davidson, B. O'Sullivan \& S. Stoynoff (Ed.), The Cambridge Guide to Second Language Assessment (pp. 140-146). New York: Cambridge University Press.

Rubio Alcalá, F. D., \& Martínez Lirola, M. (2008). La comunicación oral del inglés en España: Influencia de los aspectos educativos y mediáticos en el éxito de aprendizaje. Porta Linguarum, 32, 51-63.

Sato, M., \& Ballinger, S. (2010). Raising Language Awareness in Peer Interaction: A CrossContext, Cross-Methodology Examination. Language Awareness, 21(1-2), 157-179.

Schmid, E. C. (2010). Developing Competencies for Using the Interactive Whiteboard to Implement Communicative Language Teaching in the English as a Foreign Language Classroom. Technology, Pedagogy and Education, 19(2), 159-172.

Storch, N., \& Aldosari, A. (2013). Pairing Learners in Pair Work Activity. Language Teaching Research, 17(1), 31-48.

Susman, G. (1983). Action Research: A Sociotechnical Systems Perpective. In G. Morgan (Ed.), Beyond Method: Strategies for Social Science Research (pp. 95-113). London: Sage Publications.

Swain, M. (2000). The Output Hypothesis and Beyond: Mediating Acquisition through Collaborative Dialogue. In J. Lantolf (Ed.), Sociocultural Theory and Second Language Learning (pp. 97-114). Oxford: Oxford University Press.

Swain, M., Brooks, L., \& Tocalli-Beller, A. (2002). Peer-Peer Dialogue as a Means of Second Language Learning. Annual Review of Applied Linguistics, 22, 171-185.

Taylor, L., \& Wigglesworth, G. (2009). Ate Two Heads Better than One? Pair Work in L2 Assessment Contexts. Language Testing, 26(3), 325-339.

Watanabe, Y., \& Swain, M. (2007). Effects of Proficiency Differences and Patterns of Pair Interaction on Second Language Learning: Collaborative Dialogue between Adult ESL Learners. Language Teaching Research, 11(2), 121-142.

Zeng, G., \& Takatsuka, S. (2009). Text-Based Peer-Peer Collaborative Dialogue in a ComputerMediated Learning Environment in the EFL Context. System, 37, 434-446. 